\title{
Predictive value of intrahepatic hepatitis B virus covalently closed circular DNA and total DNA in patients with acute hepatitis $B$ and patients with chronic hepatitis $B$ receiving anti-viral treatment
}

\author{
PENG RUAN $^{1 *}$, BOPING ZHOU $^{2 *}$, XIUFANG DAI $^{3}$, ZEQUN SUN $^{3}$, \\ XIAOYAN GUO ${ }^{2}$, JIAN HUANG ${ }^{2}$ and ZUOJIONG GONG ${ }^{1}$ \\ ${ }^{1}$ Department of Infectious Diseases, Renmin Hospital of Wuhan University, Wuhan, Hubei 430060; \\ ${ }^{2}$ The Institute of Hepatology, Shenzhen Third People's Hospital, Guangdong Medical College, \\ Shenzhen, Guangdong 518112; ${ }^{3}$ Department of Gastroenterology, Renmin Hospital, \\ Hubei University of Medicine, Shiyan, Hubei 442000, P.R. China
}

Received August 5, 2013; Accepted January 29, 2014

DOI: $10.3892 / \mathrm{mmr} .2014 .1972$

\begin{abstract}
This study aimed to investigate the persistence and predictive values of intrahepatic (IH) hepatitis B virus (HBV) covalently closed circular DNA (cccDNA) and total DNA (tDNA) in patients with acute hepatitis B (AHB) and patients with chronic hepatitis $\mathrm{B}(\mathrm{CHB})$ receiving anti-viral treatment. The levels of IH cccDNA and tDNA, serum HBV DNA, hepatitis B surface antigen (HBsAg), hepatitis B e antigen $(\mathrm{HBeAg})$ and alanine aminotransferase (ALT) were detected in 11 patients with AHB and 46 patients with $\mathrm{CHB}$ who were receiving anti-viral treatment, among whom 21 had primary treatment failure, 11 achieved virological response (VR) and 15 achieved VR and HBsAg seroclearance. The median IH cccDNA and tDNA levels in the patients with AHB (0.002 copies/cell and 0.04 copies/cell, respectively) were significantly lower than those in the patients with CHB. In the patients with CHB, the median IH cccDNA level among individuals who achieved VR and HBsAg seroclearance $(0.012$ copies/cell) was significantly lower than that in those who had failed primary treatment $(4.18$ copies/cell, $\mathrm{P}<0.0001)$ but not that in those who achieved solely VR ( 0.039 copies/cell, $\mathrm{P}=0.169)$. The median IH tDNA level in patients with CHB who achevied VR and HBsAg seroclearance ( 0.096 copies/cell) was significantly lower than that in those who failed primary treatment (371 copies/cell, $\mathrm{P}<0.0001)$ and those who achieved solely VR (1.62 copies/cell, $\mathrm{P}=0.001)$. No significant difference
\end{abstract}

Correspondence to: Dr Zuojiong Gong, Department of Infectious Diseases, Renmin Hospital of Wuhan University, Jiefang Road 238, Wuhan, Hubei 430060, P.R. China

E-mail: zjgong@163.com

*Contributed equally

Key words: hepatitis B virus, covalently closed circular DNA, acute hepatitis B, chronic hepatitis B, hepatitis B surface antigen, hepatitis $\mathrm{B}$ e antigen was observed in the area under the receiver operating characteristic (ROC) curve, which was used to predict the likelihood of achieving VR and HBsAg seroclearance, between IH tDNA and IH cccDNA levels (0.96 and 0.88, respectively; $\mathrm{P}>0.10$ ). IH cccDNA levels were shown to be positively correlated with serum ALT $(\mathrm{P}=0.024), \mathrm{HBeAg}(\mathrm{P}=0.001)$ and IH tDNA levels $(\mathrm{P}<0.0001)$, but not with serum HBV DNA $(\mathrm{P}=0.12)$ and HBsAg levels in either HBeAg-positive $(\mathrm{P}=0.84)$ or in $\mathrm{HBeAg-negative}(\mathrm{P}=0.146)$ patients. In conclusion, $\mathrm{IH}$ cccDNA may persist in patients with AHB and patients with CHB who acheive VR and HBsAg seroclearance following anti-viral treatment. Furthermore, IH cccDNA and tDNA may have potential in predicting successful therapeutic response in patients with $\mathrm{CHB}$ who receive anti-viral treatment.

\section{Introduction}

Hepatitis B virus (HBV) infection is a predominant global health concern with $>350$ million individuals chronically infected worldwide. Approximately one million mortalities occur annually due to the long-term complications associated with HBV infection (1). Following infection of hepatoctyes, HBV relaxed-circle DNA (rcDNA) is transferred to the nucleus where it forms covalently closed circular DNA (cccDNA), which represents the intracellular template of the virus. Within infected cells, the pregenomic RNA (pgRNA) is then transcribed from the cccDNA and transported to the cytoplasm, where the mature capsids of the rcDNA are reverse transcribed and either secreted from the cells or returned to the nucleus to form the cccDNA pool. While HBV is a non-cytopathic virus, the immune response against virus-infected liver cells and the production of inflammatory cytokines have been proposed to be responsible for liver disease and viral clearance (2).

$\mathrm{HBV}$ infections are predominantly divided into either self-limited acute hepatitis B (AHB), inactive hepatitis B surface antigen (HBsAg) carriers, chronic hepatitis B (CHB) and occult HBV infection (OBI) (3). AHB is characterized by transient liver inflammation and virusemia. CHB consists of four phases: Immune-tolerant (IT), immune-clearance 
(IC), non/low-replicative (LR) and hepatitis B e antigen (HBeAg)-negative hepatitis (ENH) (4). Patients are classified as having the OBI form of the disease if they have undetectable HBsAg, but detectable HBV DNA in the sera or liver tissues (5). Anti-viral drug treatment for patients with $\mathrm{CHB}$ predominantly involves interferon- $\alpha($ INF- $\alpha)$ and nucleoside analogues (NUC), including lamivudine, adefovir and entecavir. However, such drugs are not capable of directly eradicating cccDNA, which has been reported to have a significant role in HBV infection relapse (6), the pathogenesis of hepatocellular carcinoma and cirrhosis (5), and the infection of liver transplant cases (7). Monitoring intrahepatic (IH) cccDNA levels in patients with $\mathrm{CHB}$ may have potential as a predictor of therapeutic response or disease progression (8). However, at present, IH HBV cccDNA and total DNA (tDNA) persistence, and the correlation between IH cccDNA and other biochemical, virological and serological parameters in patients with $\mathrm{AHB}$ and those with $\mathrm{CHB}$ who are receiving anti-viral treatment have yet to be elucidated.

This study aimed to investigate the persistence of $\mathrm{IH}$ cccDNA and tDNA and their correlation in patients with AHB and those with $\mathrm{CHB}$ receiving anti-viral treatment. Furthermore, the present study aimed to obtain and compare the thresholds of IH cccDNA and tDNA levels in order to assess successful therapeutic outcome for patients with $\mathrm{CHB}$, which may be beneficial in determining an anti-viral treatment endpoint.

\section{Patients and methods}

Patients and samples. Liver biopsy specimens were collected from a total of 60 patients, including 11 patients with AHB who achieved spontaneous virological seroclearance, 46 patients with CHB in phase III antiviral clinical trials receiving NUC (adefovir, $10 \mathrm{mg} /$ day or lamivudine, $100 \mathrm{mg} /$ day), either as a monotherapy or with pegylated-INF- $\alpha$ (100 $\mu \mathrm{g} /$ week) and three patients with autoimmune hepatitis (AIH) as negative controls. Patients who were coinfected with hepatitis D, hepatitis $\mathrm{C}$ or human immunodeficiency virus, or those with Wilson's disease, primary biliary cirrhosis or with a substantial daily alcohol intake (20 g/day for females; $30 \mathrm{~g} /$ day for males) were excluded from the study. Among the patients with $\mathrm{CHB}$, 21 had failed primary treatment, 11 had achieved virological response (VR) and 14 had achieved VR and HBsAg seroclearance and had been relapse-free for $>6$ months. Each patient signed an informed consent document approved by the Ethics Committee of Shenzhen Third People's Hospital (Shenzhen, China). Biopsy specimens were frozen in liquid nitrogen and stored at $-80^{\circ} \mathrm{C}$ until experimental analysis.

IH HBV cccDNA quantification. DNA was extracted from biopsy specimens using the QIAamp ${ }^{\circledR}$ DNA Mini kit (Qiagen, Hilden, Germany). To enhance the specificity of cccDNA detection, the Plasmid-Safe ${ }^{\mathrm{TM}}$ ATP-Dependent DNase (PSAD; Epicentre Biotechnologies, Madison, WI, USA) was used to degrade rcDNA and single-stranded DNA (ssDNA) prior to quantitative polymerase chain reaction (qPCR) analysis, according to the manufacturer's instructions (9). IH cccDNA levels were measured using qPCR analysis as described previously (9). Two forward primers, [CCC1, 5'-GCGGWCTCC
CCGTCTGTGCC-3'; diaphanous-related formin 1 (DRF1), 5'-GTCTGTGCCTTCTCATCTGC-3'], and one reverse primer, (CCC2, 5'-GTC ATGCCCCAAAGCCACC-3'), were used for cccDNA amplification using the LightCycler ${ }^{\circledR}$ system (Roche Diagnostics, Mannheim, Germany) and SYBR Premix Ex Taq (Takara Bio Inc., Otsu, Japan). Serial dilutions of a plasmid containing an HBV monomer (pHBVEcoRI) served as a quantification standard. $\beta$-globin DNA (house keeping gene) was detected using the LightCycler ${ }^{\circledR}$ Control kit DNA (Roche Diagnostics) in order to count the cell number in the biopsies and calculate copies/cell.

Serum and IH HBV tDNA quantification. Blood was collected on the day of the liver biopsy and serum was immediately stored at $-20^{\circ} \mathrm{C}$. DNA was extracted from $200 \mu \mathrm{l}$ serum using the QIAamp ${ }^{\circledR}$ DNA Blood Mini kit (Qiagen). Prior to degradation using PSAD, serum and IH tDNA levels were measured using the Cobas ${ }^{\circledR}$ TaqMan ${ }^{\circledR}$ test as described previously (Roche Diagnostics) (10).

Serum HBsAg and HBeAg quantification. Serum HBsAg and $\mathrm{HBeAg}$ levels were quantified by enzyme immunoassay using the Abbott ARCHITECT platform (Abbott Laboratories, Chicago, IL, USA) according to the manufacturer's instructions. $\mathrm{HBsAg}>0.05 \mathrm{IU} / \mathrm{ml}$ and $\mathrm{HBeAg}>1 \mathrm{IU} / \mathrm{ml}$ were considered to be positive results.

Serum alanine aminotransferase (ALT) quantification. Serum ALT levels were measured using blood chemistry analyses (DiaSys Diagnostic Systems, Holzheim, Germany), according to the manufacturer's instructions.

Statistical analysis. Statistical analyses were performed using the SPSS 13.0 statistical software (SPSS Inc., Chicago, IL, USA). Continuous variables are expressed as the mean with the range, and were analyzed using the Mann-Whitney rank sum test or one-way analysis of variance. Serum HBsAg and $\mathrm{HBeAg}$ (IU/ml) levels were logarithmically transformed prior to analysis. Categorical variables were compared using Pearson's $\chi^{2}$ test. Correlations were analyzed using Pearson's correlation coefficient. Area under the receiver operating characteristic (ROC) curve analysis was performed to predict the likelihood of achieving VR in combination with $\mathrm{HBsAg}$ seroclearance in the patients with $\mathrm{CHB}$. Two-sided $\mathrm{P}<0.05$ was considered to indicate a statistically significant difference.

\section{Results}

Baseline characteristics. The clinical, biochemical and serological characteristics of the patient groups used in this study are shown in Table I. Among the 11 patients with AHB, all patients were $\mathrm{HBeAg}$-negative $\left(\mathrm{HBeAg}^{-}\right)$, and one patient was also anti-hepatitis $\mathrm{B}$ core antibody-positive (anti- $\mathrm{HBcAb}{ }^{+}$). Among the patients with $\mathrm{CHB}$ who had failed primary treatment, three patients were $\mathrm{HBeAg}^{-}$and anti- $\mathrm{HBcAb}^{-}$, and the remaining 18 patients were $\mathrm{HBeAg}^{+}$and anti- $\mathrm{HBcAb}^{+}$. In the group of patients with $\mathrm{CHB}$ who had achieved VR, six patients were $\mathrm{HBeAg}^{-}$, of whom two patients were anti-HBcAb${ }^{+}$, and five patients were $\mathrm{HBeAg}^{+}$and anti-HBcAb${ }^{+}$. In the group 
Table I. Clinical, serological and biochemical parameters of patients.

Patient groups

\begin{tabular}{|c|c|c|c|c|c|}
\hline \multirow[b]{3}{*}{ Parameters } & \multicolumn{4}{|c|}{ Patient groups } & \multirow[b]{3}{*}{ P-value } \\
\hline & \multirow[b]{2}{*}{ AHB } & \multicolumn{3}{|c|}{$\mathrm{CHB}$ receiving anti-viral treatment } & \\
\hline & & 1 & 2 & 3 & \\
\hline Age (years) & $28.18(21-41)$ & $32.86(22-42)$ & $37.18(27-73)$ & $36.93(21-55)$ & 0.062 \\
\hline $\mathrm{HBeAg}^{+} / \mathrm{HBeAg}^{-}$ & $0 / 11$ & $18 / 3$ & $5 / 6$ & $3 / 11$ & $<0.0001$ \\
\hline Gender $(\mathrm{M} / \mathrm{F})$ & $10 / 1$ & $19 / 2$ & $9 / 2$ & $11 / 3$ & 0.713 \\
\hline $\operatorname{ALT}(\mathrm{IU} / \mathrm{ml})$ & $34.27(12-83)$ & $76.86(29-262)$ & $36.27(14-102)$ & $25.57(15-36)$ & 0.001 \\
\hline $\mathrm{HBeAg}\left(\log _{10} \mathrm{IU} / \mathrm{ml}\right)$ & $-0.42(-1-0.009)$ & $1.42(-1-3.10)$ & $0.59(-0.77-2.49)$ & $-0.44(-2-0.74)$ & $<0.0001$ \\
\hline HBsAg $\left(\log _{10} \mathrm{IU} / \mathrm{ml}\right)$ & $0.61(-0.19-3.45)$ & $3.01(1.49-4.76)$ & $3.41(1.54-5.06)$ & $-1.43(-2.52-0.10)$ & $<0.0001$ \\
\hline HBV DNA (copies/ml) & 0 & $1.33 \times 10^{7}\left(2.32 \times 10^{4}-9.07 \times 10^{7}\right)$ & 0 & 0 & 0.120 \\
\hline
\end{tabular}

1, Patients with CHB who failed primary treatment; 2, patients with CHB who achieved VR; and 3, patients with CHB who achieved VR and HBsAg seroclearance. ALT, alanine aminotransferase; HBV, hepatitis B virus; HBsAg, hepatitis B virus surface antigen; HBeAg, hepatitis B e antigen; AHB, acute hepatitis B; $\mathrm{CHB}$, chronic hepatitis B; VR, virological response; M, male; F, female.

of patients with $\mathrm{CHB}$ who had achieved VR and HBsAg seroclearance, 11 patients were $\mathrm{HBeAg}^{-}$and anti-HBcAb${ }^{-}$and three patients were $\mathrm{HBeAg}^{+}$and anti-HBcAb${ }^{+}(\mathrm{P}<0.0001)$.

IH cccDNA and tDNA quantification. The lower limits of detection for IH cccDNA and tDNA quantification were 0.00024 copies/cell and 0.0001 copies/cell, respectively. IH cccDNA levels were detectable in four patients with AHB, 21 patients with $\mathrm{CHB}$ who had failed primary treatment, 10 patients who had achieved VR and 11 patients who had achieved VR and HBsAg seroclearance. IH tDNA levels were detectable in 10 patients with AHB, 21 patients with $\mathrm{CHB}$ who had failed primary treatment, 11 patients who had achieved VR, 13 patients who had achieved VR and HBsAg seroclearance and one patient with AIH. The median IH cccDNA level in patients with AHB (0.002 copies/cell; range, $<0.00024-0.013$ ) was identified to be significantly lower than that in patients with $\mathrm{CHB}$ who had failed primary treatment (4.18 copies/cell; range, 0.078-42.4; $\mathrm{P}<0.0001$ ) as well as that in patients with $\mathrm{CHB}$ who had achieved VR (0.039 copies/cell; range, $<0.00024-0.17 ; \mathrm{P}=0.005)$ but not that in patients with $\mathrm{CHB}$ who had achieved VR and $\mathrm{HBsAg}$ seroclearance (0.012 copies/cell; range, <0.00024-0.093; $\mathrm{P}=0.076)$. The median IH tDNA level in patients with AHB (0.04 copies/cell; range, <0.0001-0.15) was observed to be significantly lower than that in patients with $\mathrm{CHB}$ who had failed primary treatment (371 copies/cell; range, 3.94-2,940; $\mathrm{P}<0.0001)$, that in patients with $\mathrm{CHB}$ who had achieved VR (1.62 copies/cell; range, 0.0039 to $5.50 ; \mathrm{P}=0.001$ ) but not that in patients with CHB who had achieved VR and HBsAg seroclearance (0.096 copies/cell; range, <0.0001-0.38; $\mathrm{P}=0.443$ ) (Fig. 1).

Among patients with $\mathrm{CHB}$, the median IH cccDNA level in those who had achieved VR and HBsAg seroclearance was observed to be significantly lower than that in those who had failed primary treatment $(\mathrm{P}<0.0001)$, but not that in those who had achieved VR $(\mathrm{P}=0.169)$. Furthermore, the median IH tDNA level in patients with CHB who had achieved VR and HBsAg seroclearance was detected to be significantly lower than that in patients with $\mathrm{CHB}$ who had failed primary treat-
Table II. Correlation between IH HBV cccDNA and tDNA levels and biochemical, virological and serological parameters.

\begin{tabular}{|c|c|c|c|c|}
\hline \multirow[b]{2}{*}{ Parameters } & \multicolumn{2}{|c|}{ IH HBV cccDNA } & \multicolumn{2}{|c|}{ IH HBV tDNA } \\
\hline & P-value & $r$ & P-value & $r$ \\
\hline Serum ALT & 0.024 & 0.294 & 0.005 & 0.369 \\
\hline Serum $\mathrm{HBeAg}$ & 0.001 & 0.480 & 0.015 & 0.321 \\
\hline \multicolumn{5}{|l|}{ Serum HBsAg } \\
\hline Serum $\mathrm{HBeAg}^{+}$patients & 0.840 & 0.038 & 0.247 & 0.236 \\
\hline Serum $\mathrm{HBeAg} \mathrm{Ag}^{-}$patients & 0.146 & 0.267 & 0.007 & 0.554 \\
\hline Serum HBV DNA & 0.121 & 0.210 & 0.437 & 0.105 \\
\hline
\end{tabular}

HBV, hepatitis B virus; IH, intrahepatic; cccDNA, covalently closed circular DNA; tDNA, total DNA; VR, virological response; HBsAg, hepatitis B surface antigen; HBeAg, hepatitis B e antigen; ALT, alanine aminotransferase.

ment $(\mathrm{P}<0.0001)$ and those who had achieved VR $(\mathrm{P}=0.001)$. As shown in Fig. 1, the median IH cccDNA and tDNA levels in patients with $\mathrm{CHB}$ who had achieved VR were significantly lower than those who had failed primary treatment $(\mathrm{P}<0.0001$ and $\mathrm{P}<0.0001$, respectively). Furthermore, Fig. 2 shows that the IH tDNA:cccDNA ratio in patients with CHB who had achieved VR and HBsAg seroclearance (20.33; range, 0-79.25) was significantly lower that in those who had failed primary treatment (380.29; range, 1.89-2,753.93; $\mathrm{P}<0.0001)$ and those who had achieved VR (155.52; range, $0-643.11 ; \mathrm{P}=0.004)$. The median IH cccDNA level in the patients who were $\mathrm{HBeAg}^{-}$(0.14 copies/cell; range, <0.00024-2.08) was significantly lower than in those who were $\mathrm{HBeAg}^{+}$ (3.24 copies/cell; range, 0.00042-42.4; $\mathrm{P}<0.0001)$. As shown in Fig. 1, the median IH tDNA level (1.38 copies/cell; range, $<0.0001-17.2)$ in the former was significantly lower than that in the latter (299 copies/cell; range, 0.070-2940; $\mathrm{P}<0.0001)$.

Correlation analysis. IH cccDNA and tDNA levels were positively correlated with serum ALT $(\mathrm{P}=0.024$ and $\mathrm{P}=0.0048$, respectively) and serum $\mathrm{HBeAg}$ levels $(\mathrm{P}=0.0001$ and $\mathrm{P}=0.015$, respectively); however, no correlation was observed 
A

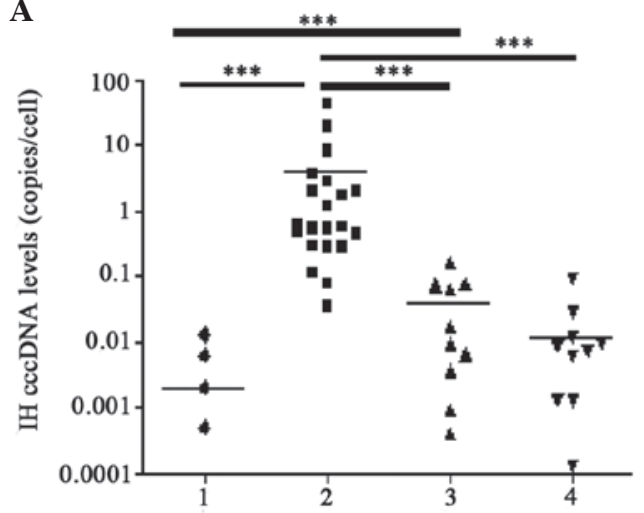

C

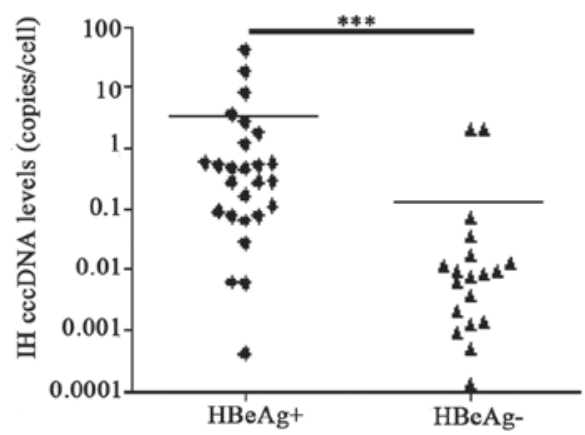

B

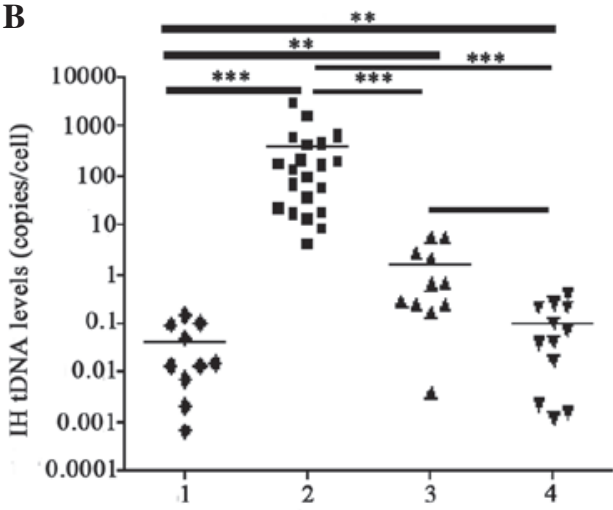

D

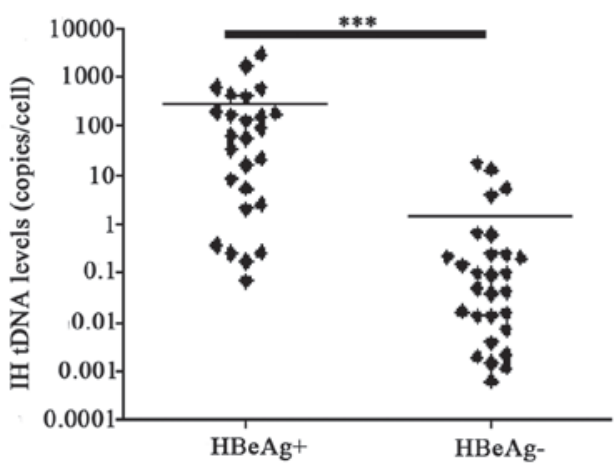

Figure 1. IH cccDNA and tDNA levels in patients with AHB and patients with CHB receiving anti-viral treatment: Group 1, patients with AHB; group 2, patients with CHB who failed primary treatment; group 3, patients with CHB who achieved VR; group 4, patients with CHB who achieved VR and HBsAg seroclearance. ${ }^{* *} \mathrm{P}<0.01 ;{ }^{* * * *} \mathrm{P}<0.001$. AHB, acute hepatitis B; CHB; chronic hepatitis B; IH, intrahepatic; cccDNA, covalently closed circular DNA; tDNA, total DNA; VR, virological response; HBsAg, hepatitis B surface antigen; HBeAg, hepatitis B e antigen.

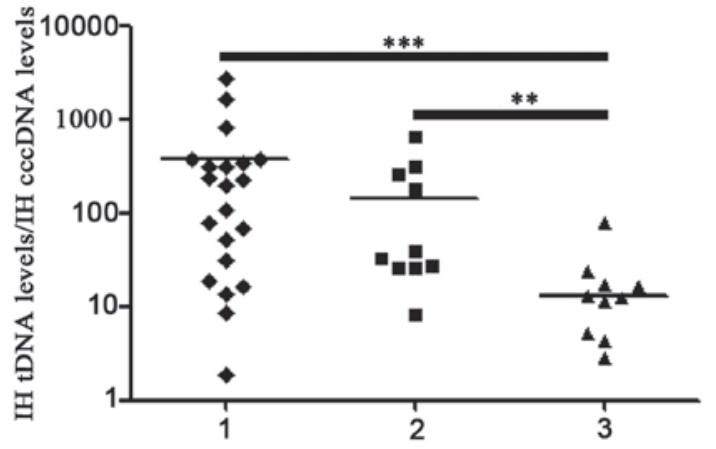

Figure 2. Ratio between IH tDNA and cccDNA in patients with CHB receiving anti-viral treatment: Group 1, patients with CHB who failed primary treatment; group 2, patients with CHB who achieved VR; group 3, patients with CHB who achieved VR and HBsAg seroclearance. ${ }^{* *} \mathrm{P}<0.01 ;{ }^{* * *} \mathrm{P}<0.001$ CHB; chronic hepatitis $\mathrm{B}$; IH, intrahepatic; cccDNA, covalently closed circular DNA; tDNA, total DNA; VR, virological response; HBsAg, hepatitis B surface antigen.

with HBV DNA levels ( $\mathrm{P}=0.121$ and $\mathrm{P}=0.437$, respectively). $\mathrm{IH}$ cccDNA levels were not observed to be correlated with serum HBsAg levels in either patients who were $\mathrm{HBeAg}^{+}(\mathrm{P}=0.84)$ or in patients who were $\mathrm{HBeAg}^{-}(\mathrm{P}=0.146)$. As shown in Table II, IH tDNA levels were positively correlated with serum HBsAg levels in patients who were $\mathrm{HBeAg}^{-}(\mathrm{P}=0.007)$, but not in those who were $\mathrm{HBeAg}^{+}(\mathrm{P}=0.247)$. IH cccDNA levels were observed to be positively correlated with IH tDNA levels $(\mathrm{P}<0.0001)$ but not with the IH tDNA:cccDNA ratio $(\mathrm{P}=0.701)$. However, as demonstrated in Fig. 3, IH tDNA levels were positively correlated with the IH tDNA:cccDNA ratio $(\mathrm{P}=0.0037)$.

Prediction for achieving VR in combination with HBsAg seroclearance. Areas under the ROC curve were used to predict the likelihood of achieving VR and HBsAg seroclearance in patients with CHB who received anti-viral treatment. The areas for IH cccDNA and tDNA levels were observed to be 0.88 [95\% confidence interval (CI): 0.78-0.98] and 0.96 (95\% CI: 0.91-1.00), respectively. As shown in Fig. 4, the cutoff value for IH cccDNA levels was 0.015 copies/cell with a sensitivity of $81.3 \%$, specificity of $85.7 \%$, positive predictive value (PPV) of $85.71 \%$ and negative predictive value (NPV) of $88.37 \%$. The cutoff value for IH tDNA levels was 0.23 copies/cell with a sensitivity of $93.8 \%$, specificity of $85.7 \%$, PPV of $85.71 \%$ and NPV of $95.35 \%(P>0.10)$.

\section{Discussion}

Approximately two billion individuals are exposed to HBV worldwide, of whom $>350$ million are chronically infected. It is well established that cellular immune responses, particularly $\mathrm{T}$ cells, contribute to $\mathrm{HBV}$ clearance. $\mathrm{CD} 4^{+} \mathrm{T}$ cells are classified into type 1 and type $2 \mathrm{~T}$ helper cells (Th1 and Th2, respectively), which differ in their patterns of secreted cytokines (11). Host immune reactions that are biased towards Th1 have been associated with AHB, with Th1-type cytokines, including IFN- $\gamma$ and tumor necrosis factor $\beta$ (TNF- $\beta$ ), potentially controlling HBV replication by activating $\mathrm{CD} 8^{+} \mathrm{T}$-cell, natural killer (NK) 
A

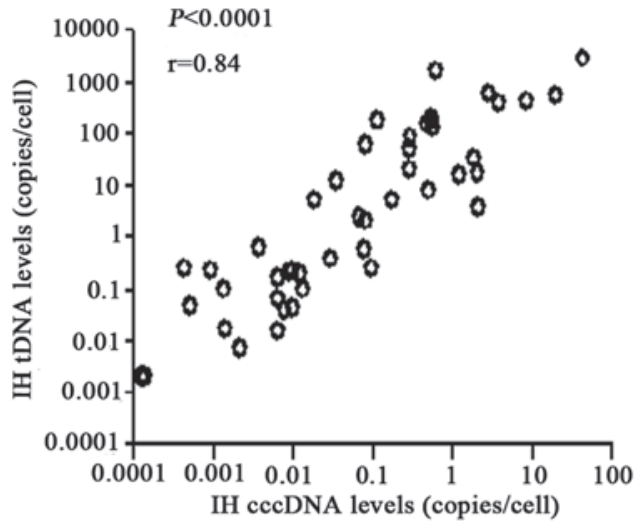

B

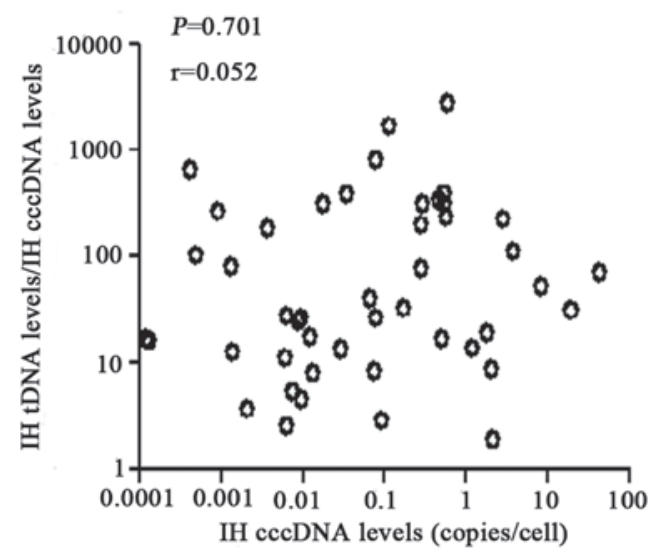

C

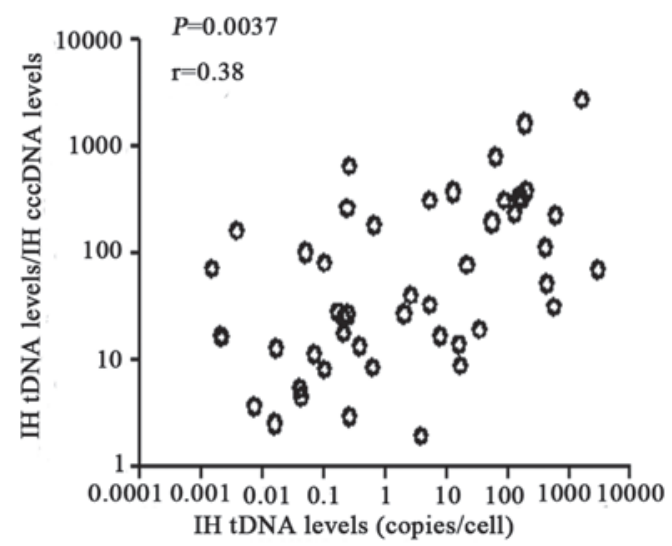

Figure 3. Correlation analysis between (A) IH cccDNA and tDNA levels; (B) IH cccDNA levels and the IH tDNA:cccDNA ratio and (C) IH tDNA levels and the IH tDNA:cccDNA ratio. IH, intrahepatic; cccDNA, covalently closed circular DNA; tDNA, total DNA.

cell and macrophage responses, consequently stimulating a cascade of inflammatory cytokines and degrading HBV RNA directly (12). Inefficiencies in the innate and adaptive immune responses may result in $\mathrm{CHB}$, in which high levels of transforming growth factor- $\beta 1$, predominantly secreted by regulatory $\mathrm{T}$ cells, may impair NK cell function by reducing natural killer group 2 member D/DNAX activation protein 10 and natural killer cell receptor 2B4/SLAM-associated protein expression, and suppress innate antiviral immunity by blocking the cell cycle in G1 (13) as well as inhibit the secretion of IFN- $\gamma$ and TNF- $\alpha$ from HBV-specific T cells (12).

In the present study, the median IH cccDNA level in patients with AHB was observed to be significantly lower than that of

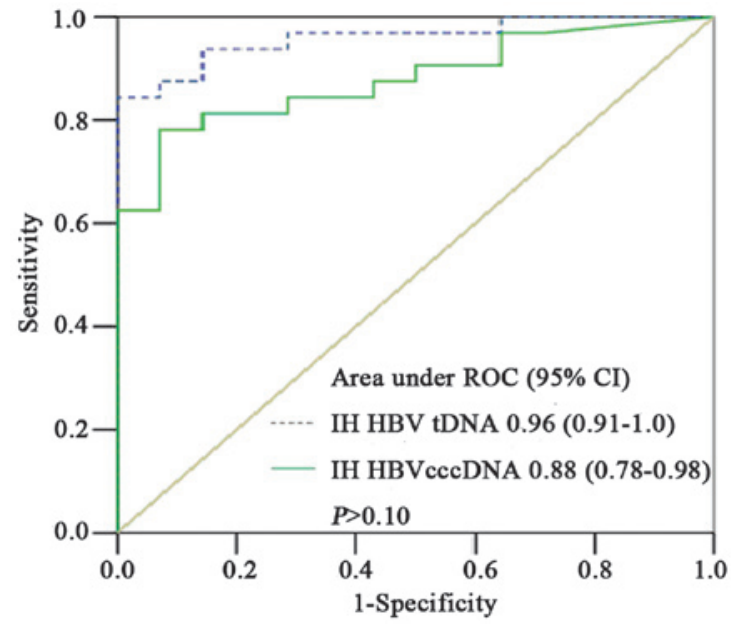

Figure 4. ROC curve of IH cccDNA and tDNA levels to predict the likelihood of achieving VR and HBsAg seroclearance in patients with $\mathrm{CHB}$ receiving anti-viral treatment. ROC, receiver operating characteristic; $\mathrm{CHB}$, chronic hepatitis B; IH, intrahepatic; HBV, heptitis B virus; cccDNA, covalently closed circular DNA; tDNA, total DNA.

the patients with CHB who were receiving anti-viral treatment. This finding suggests that in patients with AHB, the immune system may be capable of reducing IH cccDNA to markedly low levels. In patients with CHB, the median IH cccDNA level in those who had achieved VR in combination with HBsAg seroclearance, was observed to be significantly lower than that in those who had failed primary treatment and those that had achieved VR. The outcome of anti-viral treatment in patients with CHB is highly variable, ranging from primary treatment failure to VR, serological response, biochemical response and virological breakthrough (14). While it has been hypothesized that clinical resolution of HBV infection occurs when HBV replication is completely controlled by the host's immune system (15), it has been suggested that achieving VR in combination with HBsAg seroclearance may be the most effective therapeutic response (16). Furthermore, the present study demonstrated that cccDNA production may be attenuated in patients with CHB who achieve VR and HBsAg seroclearance following anti-viral treatment.

To predict the likelihood of achieving VR and HBsAg seroclearance following anti-viral treatment in patients with CHB, the areas under the ROC curves of IH tDNA and cccDNA levels were compared. The area under the ROC curve of IH tDNA levels was observed to be higher than that of IH cccDNA levels (0.96 vs. 0.88 ); however, the difference was not statistically significant $(\mathrm{P}>0.10)$. This may be explained by changes in virion productivity, which was defined as the ratio between IH HBV tDNA and cccDNA levels and reflected the level of cccDNA transcription (17). In the present study, while the IH tDNA:cccDNA ratio was significantly lower in patients with CHB who achieved VR and HBsAg seroclearance, it was revealed to be positively correlated with IH tDNA, but not cccDNA levels. IH cccDNA transcription is tightly controlled by various intrinsic factors, including methylation and acetylation of $\mathrm{H} 3$ and $\mathrm{H} 4$ histones in cccDNA minichromosomes $(18,19)$ and recruitment of transcription factors, including histone deacetylase 1 , sirtuin 1 , enhancer of zeste homolog 2 and yin yang 1 (20). Effective anti-viral treatment may be beneficial to 
control cccDNA transcription and consequently reduce virion productivity. In addition, it has been reported that amplification of the cccDNA pool may be suppressed by a negative-feedback mechanism involving the viral large surface protein (15), and $\mathrm{HBeAg}$ loss may significantly impair virion productivity (21). Such reports are verified by the present study, in which the proportion of $\mathrm{HBeAg}^{-}$patients was observed to be significantly higher in the group of patients with $\mathrm{CHB}$ who had achieved VR and HBsAg seroclearance. A previous report indicated that in patients with $\mathrm{CHB}$ who had achieved therapeutic response with adefovir, the reduction rate of IH tDNA levels was significantly higher than that of cccDNA levels (22). However, it has also been reported that IH tDNA levels may be as sensitive as IH cccDNA levels for predicting the likelihood of achieving sustained virological response (SVR) (8), although achieving VR in combination with HBsAg seroclearance is likely to be more effective than achieving SVR in anti-viral treatment. The findings of the present study reveal a potentially novel therapeutic strategy for suppressing virion productivity through reducing the size of the cccDNA pool rather than through eradicating IH cccDNA completely.

IH cccDNA was not detected in the negative controls employed in the present study, however tDNA persistence was detected in one patient, being diagnosed as OBI. This finding may be attributed to the complex composition of IH tDNA, which aside from rcDNA, consists of linear DNA, including double linear DNA (dlDNA), as well as single-stranded DNA (ssDNA). Certain linear DNA molecules, produced through illegitimate replication and deficient HBV transcription (23), may be present in hepatocytes but not secreted into the blood (24). Alternatively, IH tDNA may be detected by means of integrated HBV (25). The findings of the present study indicate that IH tDNA detection may be valuable in the diagnosis of OBI in patients with hepatitis without HBV virusemia.

While cryo-preserved liver tissue is not always available clinically, serum HBsAg has been regarded as a surrogate marker for assessing IH cccDNA levels (21). Previous reports observed that serum HBsAg levels were positively correlated with IH cccDNA levels in patients with $\mathrm{CHB}$ who were $\mathrm{HBeAg}^{+}$, but not in those who were $\mathrm{HBeAg}^{-}(26,27)$. However, in the present study, no significant correlation was observed between serum HBsAg and IH cccDNA levels in either $\mathrm{HBeAg}^{+}$or $\mathrm{HBeAg}^{-}$patients. This may be a consequence of HBsAg production, which is complex, abundant and far exceeding that required for virion assembly, being independent of HBV replication (28), or the occurrence of increased $\mathrm{HBsAg}$ translation in $\mathrm{HBeAg}^{-}$patients as a compensatory mechanism to adapt to the increased immunological pressure (17). Alternatively, HBsAg may be produced from integrated HBV (26), or IH cccDNA copies may be reduced by anti-viral treatment (29).

It was observed in the present study that IH cccDNA levels were positively correlated with serum $\mathrm{HBeAg}$ levels and that IH cccDNA and tDNA levels were significantly lower in $\mathrm{HBeAg}^{-}$patients than in $\mathrm{HBeAg}^{+}$patients. $\mathrm{HBeAg}$ has been reported to have an important role in $\mathrm{HBV}$ persistence, and $\mathrm{HBeAg}$ seroconversion has been suggested to increase Th1 cytokine secretion to inhibit HBV replication (12). The findings of the present study are in accordance with a previous study that demonstrated that pre-core mRNA was solely transcribed from the cccDNA template and not the integrated $\mathrm{HBV}$, and that serum $\mathrm{HBeAg}$ detection may serve as a cccDNA surrogate in anti-viral screening assays (30).

In the present study, IH cccDNA levels were observed to be positively correlated with IH tDNA but not serum HBV DNA levels. This poor correlation between IH cccDNA and serum HBV DNA levels may be partially attributed to the fact that a number of patients were virusemia negative and indicates that serum HBV DNA levels may not represent an ideal biomarker for evaluating IH HBV production. CHB is a necroinflammatory liver disease and it has been suggested that raised serum ALT levels may predict activation of the host immune system, hepatocyte damage and increased cell proliferation (31). The positive correlation between serum ALT levels and IH cccDNA and tDNA levels observed in the present study indicate that cccDNA replication may have a role in the progression of $\mathrm{HBV}$ inflammation.

In conclusion, the present study showed that extremely low levels of IH cccDNA may be present in patients with AHB and patients with $\mathrm{CHB}$ who achieve VR and HBsAg seroclearance following anti-viral treatment. IH cccDNA levels were identified to be positively correlated with IH tDNA, serum $\mathrm{HBeAg}$ and ALT levels, and not correlated with serum HBV DNA and HBsAg levels. Therefore, IH cccDNA and tDNA have potential value for the prediction of a successful therapeutic response in patients with $\mathrm{CHB}$ receiving anti-viral treatment, and the latter may also be beneficial in OBI diagnosis.

\section{Acknowledgements}

The authors would like to thank XC Chen and M Wang from the Institute of Hepatology, Shenzhen Third People's Hospital for their technical assistance.

\section{References}

1. Lok AS and McMahon BJ: Chronic Hepatitis B. Hepatology 45: 507-539, 2007.

2. Jiang YF, Ma ZH, Zhao PW, Pan Y, Liu YY, Feng JY and Niu JQ: Effect of thymosin- $\alpha(1)$ on T-helper 1 cell and T-helper 2 cell cytokine synthesis in patients with hepatitis B virus e antigen-positive chronic hepatitis B. J Int Med Res 38: 2053-2062, 2010.

3. European association for the study of the liver: EASL Clinical Practice Guidelines: management of chronic hepatitis B. J Hepatol 50: 227-242, 2009.

4. Nguyen T, Thompson AJ, Bowden S, et al: Hepatitis B surface antigen levels during the natural history of chronic hepatitis B: a perspective on Asia. J Hepatol 52: 508-513, 2010.

5. Wong DK, Huang FY, Lai CL, et al: Occult hepatitis B infection and HBV replicative activity in patients with cryptogenic cause of hepatocellular carcinoma. Hepatology 54: 829-836, 2011.

6. Lau GK, Liang R, Chiu EK, Lee CK and Lam SK: Hepatic events after bone marrow transplantation in patients with hepatitis $B$ infection: a case controlled study. Bone Marrow Transplant 19: 795-799, 1997.

7. Chaiteerakij R, Komolmit P, Sa-nguanmoo P and Poovorawan Y: Intrahepatic HBV DNA and covalently closed circular DNA (cccDNA) levels in patients positive for anti-HBc and negative for HBsAg. Southeast Asian J Trop Med Public Health 41: 867-875, 2010.

8. Sung JJ, Wong ML, Bowden S, et al: Intrahepatic hepatitis B virus covalently closed circular DNA can be a predictor of sustained response to therapy. Gastroenterology 128: 1890-1897, 2005.

9. Bowden S, Jackson K, Littlejohn $M$ and Locarnini S: Quantification of HBV covalently closed circular DNA from liver tissue by real-time PCR. Methods Mol Med 95: 41-50, 2004. 
10. Weinberger KM, Wiedenmann E, Böhm S and Jilg W: Sensitive and accurate quantitation of hepatitis B virus DNA using a kinetic fluorescence detection system (TaqMan PCR). J Virol Methods 85: 75-82, 2000.

11. Ramezani A, Banifazl M, Mamishi S, Sofian M, Eslamifar A and Aghakhani A: The influence of human leukocyte antigen and IL-10 gene polymorphisms on hepatitis B virus outcome. Hepat Mon 12: 320-325, 2012.

12. Chang JJ and Lewin SR: Immunopathogenesis of hepatitis B virus infection. Immunol Cell Biol 85: 16-23, 2007.

13. Sun C, Fu B, Gao Y, Liao X, Sun R, Tian Z and Wei H: TGF- $\beta 1$ down-regulation of NKG2D/DAP10 and 2B4/SAP expression on human NK cells contributes to HBV persistence. PLoS Pathog 8 : e1002594, 2012.

14. Chinese Society of Hepatology and Chinese Society of Infectious Diseases; Chinese Medical Association: The guideline of prevention and treatment for chronic hepatitis B (2010 version) Zhonghua Gan Zang Bing Za Zhi 19: 13-24, 2011 (In Chinese).

15. Levrero M, Pollicino T, Petersen J, Belloni L, Raimondo G and Dandri M: Control of cccDNA function in hepatitis B virus infection. J Hepatol 51: 581-592, 2009.

16. Wang M, Qiu N, Lu S, et al: Serum hepatitis B surface antigen is correlated with intrahepatic total HBV DNA and cccDNA in treatment-naïve patients with chronic hepatitis B but not in patients with HBV related hepatocellular carcinoma. J Med Virol 85: 219-227, 2013.

17. Manesis EK, Papatheodoridis GV, Tiniakos DG, et al: Hepatitis B surface antigen: relation to hepatitis B replication parameters in HBeAg-negative chronic hepatitis B. J Hepatol 55: 61-68, 2011.

18. Pollicino T, Belloni L, Raffa G, Pediconi N, Squadrito G Raimondo $\mathrm{G}$ and Levrero M: Hepatitis B virus replication is regulated by the acetylation status of hepatitis B virus cccDNA-bound $\mathrm{H} 3$ and $\mathrm{H} 4$ histones. Gastroenterology 130: 823-837, 2006

19. Vivekanandan P, Thomas D and Torbenson M: Methylation regulates hepatitis B viral protein expression. J Infect Dis 199: 1286-1291, 2009.

20. Belloni L, Allweiss L, Guerrieri F, et al: IFN- $\alpha$ inhibits HBV transcription and replication in cell culture and in humanized mice by targeting the epigenetic regulation of the nuclear cccDNA minichromosome. J Clin Invest 122: 529-537, 2012.

21. Volz T, Lutgehetmann M, Wachtler P, et al: Impaired intrahepatic hepatitis B virus productivity contributes to low viremia in most $\mathrm{HBeAg}$-negative patients. Gastroenterology 133: $843-852,2007$
22. Werle-Lapostolle B, Bowden S, Locarnini S, et al: Persistence of cccDNA during the natural history of chronic hepatitis B and decline during adefovir dipivoxil therapy. Gastroenterology 126: $1750-1758,2004$

23. Chou YC, Jeng KS, Chen ML, et al: Evaluation of transcriptional efficiency of hepatitis B virus covalently closed circular DNA by reverse transcription-PCR combined with the restriction enzyme digestion method. J Virol 79: 1813-1823, 2005.

24. Xu WS, Zhao KK, Miao XH, Ni W, Cai X, Zhang RQ and Wang JX: Effect of oxymatrine on the replication cycle of hepatitis B virus in vitro. World J Gastroenterol 16: 2028-2037, 2010.

25. Jiang Z, Jhunjhunwala S, Liu J, et al: The effects of hepatitis B virus integration into the genomes of hepatocellular carcinoma patients. Genome Res 22: 593-601, 2012.

26. Thompson AJ, Nguyen T, Iser D, et al: Serum hepatitis B surface antigen and hepatitis B e antigen titers: disease phase influences correlation with viral load and intrahepatic hepatitis B virus markers. Hepatology 51: 1933-1944, 2010.

27. Jaroszewicz J, Calle Serrano B, Wursthorn K, et al: Hepatitis B surface antigen ( $\mathrm{HBsAg}$ ) levels in the natural history of hepatitis B virus (HBV)-infection: A European perspective. J Hepatol 52: 514-522, 2010.

28. Chan HL, Wong VW, Tse AM, et al: Serum hepatitis B surface antigen quantitation can reflect hepatitis B virus in the liver and predict treatment response. Clin Gastroenterol Hepatol 5: $1462-1468,2007$

29. Takkenberg RB, Zaaijer HL, Menting S, et al: Detection of hepatitis B virus covalently closed circular DNA in paraffin-embedded and cryo-preserved liver biopsies of chronic hepatitis B patients. Eur J Gastroenterol Hepatol 22: 952-960, 2010.

30. Zhou T, Guo H, Guo JT, Cuconati A, Mehta A and Block TM: Hepatitis B virus e antigen production is dependent upon covalently closed circular (ccc) DNA in HepAD38 cell cultures and may serve as a cccDNA surrogate in antiviral screening assays. Antiviral Res 72: 116-124, 2006.

31. Moucari R, Mackiewicz V, Lada O, et al: Early serum HBsAg drop: a strong predictor of sustained virological response to pegylated interferon alfa-2a in $\mathrm{HBeAg}$-negative patients. Hepatology 49: 1151-1157, 2009. 